\title{
Penerapan Model Belajar Berbasis Riset dalam Mengembangkan Civic Skills Mahasiswa
}

\author{
Novitasari', Achmad Busrotun Nufus \\ Prodi Pendidikan Bahasa dan Sastra Indonesia Fakultas Keguruan dan Ilmu Pendidikan Universitas \\ Tidar, Indonesia \\ 1bbqenak@untidar.ac.id
}

\begin{abstract}
ABSTRAK
Pembelajaran mata kuliah Kewarganegaraan memiliki tujuan menciptakan lulusan yang memiliki civic competencies sehingga dapat menjadi warga negara yang baik. Akan tetapi, pembelajaran kewarganegaraan cenderung dilaksanakan dengan model pembelajaran yang berpusat pada dosen sehingga dosen sebagai satu-satunya sumber belajar, sedangkan kompetensi kewarganegaraan khususnya civic skills tidak dapat diperoleh hanya dengan mentransfer pengetahuan. Penelitian ini bertujuan untuk menganalisis penggunaan model belajar berbasis riset dalam meningkatkan civic skills mahasiswa pada mata kuliah Kewarganegaraan. Penelitian ini menggunakan penelitian tindakan kelas dengan pendekatan kualitatif. Data dikumpulkan melalui observasi, wawancara, dan studi dokumentasi. Hasil penelitian menggambarkan bahwa penerapan model belajar berbasis riset dapat melatih mahasiswa untuk terbiasa berpikir kritis dan memiliki keterampilan partisipasi. Berdasarkan hasil penelitian, penulis merekomendasikan antara lain: (a) bagi pendidik, memetakan kebutuhan dan kemampuan belajar peserta didik di awal semester atau tahun ajaran baru sehingga dapat menggunakan model pembelajaran yang efektif; (b) bagi peneliti selanjutnya, mencoba menggunakan model belajar berbasis riset pada responden yang berbeda atau mata kuliah yang lain sehingga dapat mengetahui efektivitas penggunaan model belajar berbasis riset secara lebih luas.
\end{abstract}

Kata kunci: Model Belajar Berbasis Riset, civic skills, kompetensi kewargaan, kewarganegaraan

\begin{abstract}
Citizenship learning aims to create graduates who have civic competencies so that they become good citizens. However, Citizenship learning tends to be implemented using a model centered on lecturers so that lecturers are the only source of learning. Meanwhile, civic competencies, particularly civic skills, cannot be obtained simply by transferring knowledge. This study aims to analyze how the use of research-based learning models can improve student civic skills in the Citizenship course. This study used classroom action research with a qualitative approach. Data were collected through observation, interviews, and documentation studies. The result of the study shows that the research-based learning model can train students to think critically and have participatory skills. Based on the results, we recommend: (a) for educators, to map students' learning needs and abilities at the beginning of a new semester or a new school year so that they can use effective learning models; (b) for other researchers, to use research-based learning models on different respondents or in other subjects so they can examine the effectivities of using research-based learning models more broadly.
\end{abstract}

Keywords: Research-Based Learning Models, civic skills, citizenship

This work is licensed under the Creative Commons Attribution-ShareAlike 4.0 International

License. (C2019 by the author(s). 


\section{PENDAHULUAN}

Perkembangan zaman dan kemajuan teknologi mendorong perubahan dalam segala bidang termasuk dalam bidang pendidikan. Pelaksanaan kegiatan belajar mengajar menuntut pembaharuan sehingga capaian pembelajaran yang diharapkan disesuaikan dengan kebutuhan era kemajuan teknologi dan informasi. Pembelajaran yang sebelumnya berfokus pada pendidik perlu diubah menjadi berfokus pada peserta didik terutama pada pembelajaran di perguruan tinggi. Harsono (2008) mengatakan bahwa paradigma pembelajaran yang berpusat pada dosen atau pendidik mengakibatkan terciptanya komunikasi satu arah sehingga mahasiswa cenderung apatis karena hanya berperan sebagai penerima dan kurang berperan sebagai pengubah atau pengeksplor. Sedangkan pada pembelajaran di perguruan tinggi, bukan lagi saatnya dosen menjadi satu-satunya sumber belajar bagi mahasiswa terutama pada pembelajaran yang menekankan pada pengembangan karakter, salah satunya pembelajaran mata kuliah Kewarganegaraan. Kesan pembelajaran yang monoton dan berjalan pelan perlu diubah menjadi pembelajaran yang aktif dan menyenangkan. Terlebih lagi materi dalam mata kuliah yang bersifat konseptual cenderung membuat mahasiswa kurang tertarik dan termotivasi apabila penyampaian materi menggunakan model pembelajaran yang tidak melibatkan mahasiswa secara aktif.

Salah satu model pembelajaran yang berpusat pada mahasiswa adalah model belajar berbasis riset. Model Belajar Berbasis Riset adalah model pembelajaran yang berpusat pada peserta didik. Menurut Sukarno (2018), model belajar berbasis riset merupakan sebuah aktivitas pembelajaran yang menekankan pada keaktifan peserta didik, sedangkan pendidik sebagai fasilitator. Model tersebut menekankan pada empat dimensi, yaitu way of thinking, way of work, tool of work, living in the world together. Lebih lanjut, Sukarno (2018) menjabarkan ciri-ciri dari model belajar berbasis riset di era pembelajaran abad ke-21, antara lain: (1) Menekankan pada keaktifan dan kemandirian belajar siswa/mahasiswa; (2) Guru/dosen bertugas sebagai fasilitator sehingga tidak mendominasi dalam proses belajar mengajar; (3) Nilai-nilai riset diintegrasikan ke dalam proses pembelajaran sehingga melatih siswa/mahasiswa menjadi seseorang yang memiliki sifat seorang peneliti/ ilmuwan/pemikir; (4) Guru/dosen aktif mengangkat permasalahan/fenomena yang terjadi di lingkungan sekitar siswa/mahasiswa dalam proses pembelajaran untuk diselidiki oleh siswa/mahasiswa sehingga pokok bahasan dalam pembelajaran bersifat kontekstual; (4) Proses pembelajaran menggunakan metode pembelajaran yang mendukung keterampilan abad ke-21, yaitu siswa/mahasiswa yang memiliki keterampilan-keterampilan penting, yaitu kreativitas (creativity), berpikir kritis (critical thinking), penyelesaian masalah (problem solving), dan pengambilan keputusan (decision making), serta pembelajaran untuk belajar dan metakognisi (learning to learn and metacognition); (5) Cara bekerja menggunakan dua komponen keterampilan yaitu komunikasi dan kolaborasi; (6) Alat untuk bekerja dibangun oleh dua keterampilan khusus yaitu literasi informasi dan literasi ICT; (7) Kecakapan hidup mengarah pada kewarganegaraan (citizenship), kehidupan dan karir, personal serta tanggung jawab. Berdasarkan ciri-ciri tersebut, model belajar berbasis riset 
dapat dilaksanakan dengan mengikuti beberapa tahapan, yaitu sebagai berikut (Sukarno, 2018): (a) Identifying the problem; (b) Framing the question; (c) Propose hypothesis; (d) Investigating; (e) Analyzing the data; (f) Evaluating hypothesis; (g) Communicating the result.

Hafsah (2017) dalam penelitiannya menyebutkan bahwa model pembelajaran berbasis riset yang dilaksanakan dalam perkuliahan mahasiswa magister akuntansi Universitas Muhammadiyah Sumatera utara dapat memperluas wawasan mahasiswa karena mahasiswa ikut aktif sehingga memperoleh pengalaman nyata yaitu dengan mencari dan mengumpulkan informasi, menganalisis data hingga membuat kesimpulan secara mandiri maupun kelompok. Selain itu, pembelajaran berbasis riset juga meningkatkan mutu pembelajaran bagi mahasiswa karena pembaharuan pembelajaran terus dilakukan dengan mengintegrasikan hasil riset dalam pembelajaran. Senada dengan Hafsah, Pratama (2017) menyimpulkan dalam penelitiannya bahwa pembelajaran berbasis riset merupakan faktor pendukung dalam upaya pencapaian apabila suatu universitas hendak menjadi berbasis riset. Selain itu, kualitas riset juga tidak kalah penting karena model pembelajaran mengintegrasikan riset dalam kegiatan belajar mengajar. Pratama (2017) menekankan bahwa model pembelajaran berbasis riset dapat menggunakan jurnal ilmiah sebagai bahan ajar karena mempunyai keunggulan dibandingkan buku teks, yaitu: dari segi waktu publikasi yang dilakukan secara periodik, kebaruan konsep lebih terjamin, proses review dilakukan oleh teman sejawat yang satu bidang, dan sumber yang digunakan berbasis data.

Rangkuti (2017) mengatakan bahwa model pembelajaran berbasis riset dapat mendorong pertumbuhan keterampilan mahasiswa dalam melakukan penelitian sehingga menciptakan budaya melakukan riset di kampus dan menjadi salah satu indikator keberhasilan suatu kampus yang berbasis riset. Beberapa kampus di Indonesia memiliki visi untuk menjadikan kampus berbasis riset, salah satunya Universitas Tidar. Visi Universitas Tidar adalah Universitas berbasis riset dalam mengembangkan ilmu pengetahuan, teknologi, seni, dan kewirausahaan. Sedangkan misinya, antara lain: (1) Mengembangkan ilmu pengetahuan, teknologi, dan seni berdasarkan pendekatan riset; (2) Melaksanakan tri dharma perguruan tinggi berdasarkan pendekatan riset; (3) Mengembangkan praktik wirausaha berdasarkan pendekatan riset; dan (4) Melaksanakan tata kelola dan tata kerja perguruan tinggi yang transparan, akuntabel, efektif, efisien, partisipatif, dan berkeadilan. Berdasarkan visi dan misi tersebut, model belajar berbasis riset sesuai dengan visi dan misi universitas sehingga perlu diterapkan pada semua pembelajaran dalam perkuliahan. Akan tetapi, dosen tetap memiliki otonomi dalam penyelenggaraan pembelajaran pada mata kuliah yang diampu masing-masing. Terlebih lagi, mata kuliah Kewarganegaraan yang pada dasarnya tidak hanya berkaitan dengan pengetahuan tetapi juga keterampilan dan sikap membutuhkan model belajar yang dapat mengantarkan menjadi warga negara yang baik yang ditandai dengan kemampuan berpikir kritis dan keterampilan partisipatif. Penelitian ini dilakukan untuk menerapkan model belajar berbasis riset pada pembelajaran Kewarganegaraan untuk melatih berpikir kritis dan kemampuan partisipatif mahasiswa. 


\section{METODE PENELITIAN}

Penelitian ini menggunakan penelitian tindakan dengan pendekatan penelitian kualitatif. Penelitian tindakan digunakan untuk memperbaiki praktik pendidikan dengan mengkaji masalah-masalah yang dihadapi, sementara penelitian tindakan kelas merupakan pengembangan dari penelitian tindakan yang bertujuan untuk memperbaiki atau meningkatkan mutu pembelajaran (Legiman, 2015). Kusnadi (2010) menyatakan bahwa penelitian tindakan adalah penelitian yang merupakan suatu langkah-langkah (a spiral of steps). Setiap langkah terdiri atas empat tahap, yaitu: perencanaan, tindakan, observasi, dan refleksi. Jumlah siklus yang dilakukan tergantung pada tingkat ketercapaian hasil penerapan pendekatan sesuai dengan rencana sehingga siklus tidak ditambah apabila sudah tidak ditemukan lagi permasalahan-permasalahan dalam melaksanakan pendekatan di kelas. Langkah-langkah penerapan penelitian tindakan kelas yaitu sebagai berikut: (1) menetapkan fokus permasalahan; (2) merencanakan tindakan; (3) melaksanakan tindakan; (4) mengumpulkan data; (5) refleksi (analisis dan evaluasi); (6) merencanakan tindak lanjut. Berikut merupakan gambar siklus rangkaian kegiatan dalam penelitian tindakan kelas.

\section{Gambar 1. Siklus Kegiatan Penelitian Tindakan Kelas}

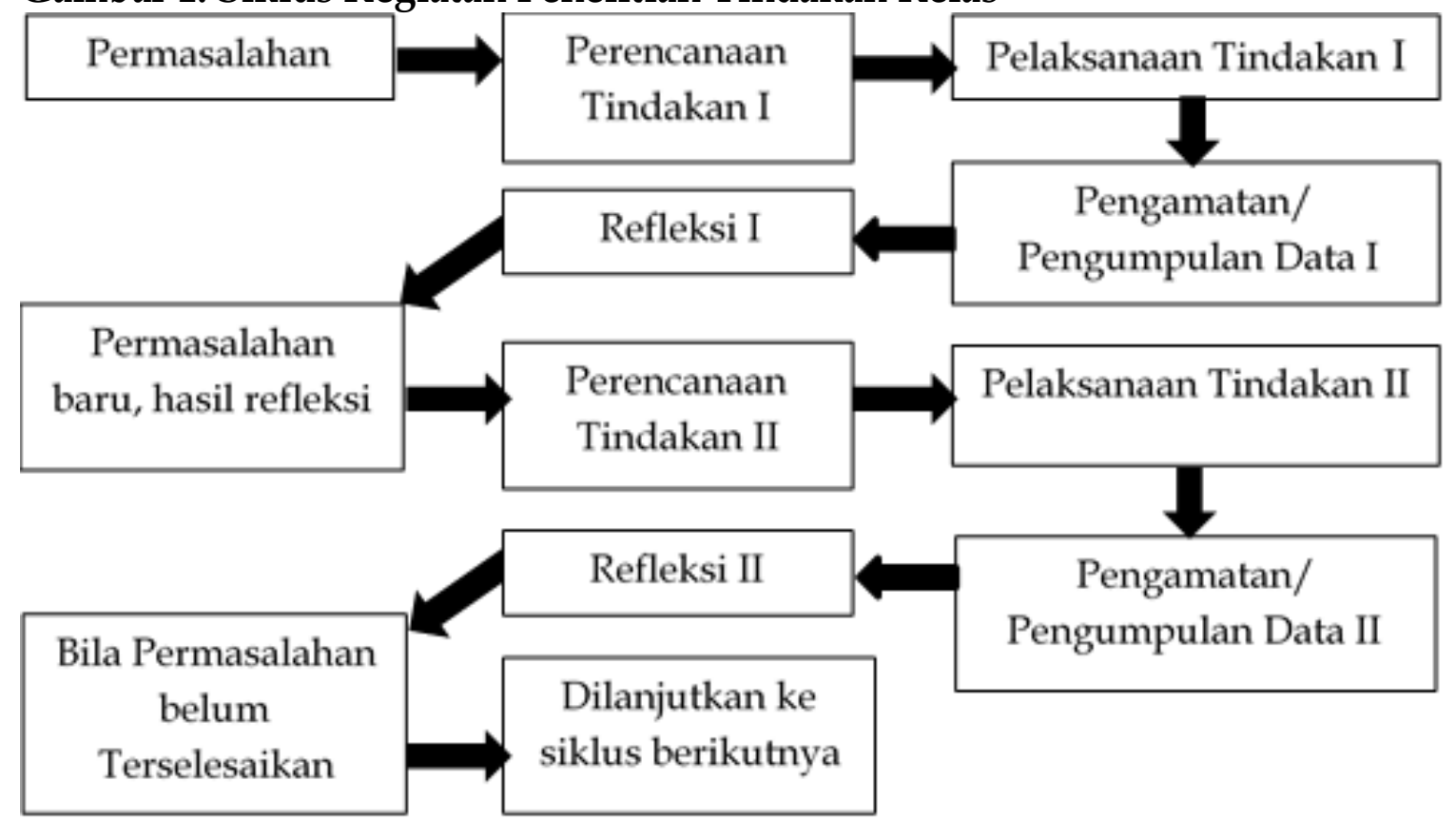

Sumber: Legiman (2015)

Pada tahap penentuan masalah, dilakukan pendekatan kualitatif dengan maksud mengeksplorasi permasalahan dan mengembangkan pemahaman secara terperinci tentang fenomena yang menjadi pokok penelitian (Creswell, 2016). Penelitian ini bertujuan untuk mengetahui dan mengembangkan pemahaman terperinci tentang suatu kondisi di Universitas Tidar dalam menerapkan model belajar berbasis riset dalam mengembangkan civic skills mahasiswa pada pembelajaran Kewarganegaraan. Tinjauan kepustakaan dalam pendekatan penelitian kualitatif dapat berkembang sesuai dengan kebutuhan temuan penelitian di lapangan.

Penelitian berlokasi di Universitas Tidar yang beralamat di Jalan Kapten 
Suparman 39, Potrobangsan, Magelang Utara, Kota Magelang, Provinsi Jawa Tengah. Universitas Tidar dipilih menjadi lokasi penelitian karena Universitas Tidar memiliki visi dan misi yang sesuai dengan variabel penelitian yang akan diteliti. Teknik pengumpulan data yang akan digunakan terdiri atas tiga macam, yaitu: tes, kuesioner, observasi, wawancara, dan studi dokumentasi. Analisis data akan dilakukan dengan menggunakan model Miles, Huberman dan Saldana (2014), yaitu: (1) reduksi data; (2) penyajian data; (3) penarikan kesimpulan dan verifikasi. Triangulasi dilakukan untuk mengecek keabsahan data dari berbagai sumber dan teknik pengumpulan data sehingga dapat dideskripsikan dan diperoleh data yang lebih spesifik.

\section{HASIL PENELITIAN DAN PEMBAHASAN}

\section{Profil Mata Kuliah Kewarganegaraan di Universitas Tidar}

Mata kuliah Kewarganegaraan di Universitas Tidar adalah salah satu Mata Kuliah Dasar Umum (MKDU) yang wajib ditempuh oleh seluruh mahasiswa D-III dan S1. Penerapan tersebut berpedoman pada Pasal 35 ayat (3) dan (5) UndangUndang Republik Indonesia Nomor 12 Tahun 2012 Tentang Pendidikan Tinggi yang menyebutkan ketentuan kurikulum Pendidikan Tinggi baik program sarjana maupun diploma wajib memuat mata kuliah: Agama, Pancasila, Kewarganegaraan, Bahasa Indonesia. Tujuan umum mata kuliah Kewarganegaraan yang termuat dalam penjelasan Pasal 35 Ayat (3) Huruf (c) adalah membentuk mahasiswa menjadi warga negara yang memiliki rasa kebangsaan dan cinta tanah air. Wahab dan Sapriya (2010)) mengatakan bahwa tujuan pendidikan kewarganegaraan adalah untuk membentuk warga negara yang baik (to be good citizen). Branson (1999) mengemukakan hal yang senada yaitu tujuan pendidikan kewarganegaraan atau civic education adalah membentuk peserta didik yang dapat berpartisipasi yang bermutu dan bertanggung jawab dalam kehidupan bermasyarakat, berbangsa dan bernegara sehingga memerlukan kompetensi kewarganegaraan. Menurut Setiawan (2015), warga negara yang baik adalah warga negara yang memiliki kompetensi kewarganegaraan sehingga pendidikan kewarganegaraan memfokuskan pada pengembangan kompetensi kewarganegaraan, antara lain: civic knowledge, civic skills, dan civic disposition.

Civic knowledge atau pengetahuan kewarganegaraan adalah materi yang harus diketahui oleh warga negara karena berkaitan dengan hak dan kewajiban sebagai warga negara dalam kehidupan bermasyarakat, berbangsa, dan bernegara. Menurut Branson (1999), komponen pengetahuan kewarganegaraan berdasarkan National Standar and Civics Framework for the 1988 National Assessment of Educational Progress (NAEP), dapat disusun dalam bentuk lima pertanyaan, antara lain: (1) Apa yang dimaksud dengan kehidupan kewarganegaraan, politik dan pemerintahan?; (2) Apa yang menjadi fondasi dalam sistem politik?; (3) Bagaimana pemerintahan yang dibentuk oleh konstitusi mengejawantahkan tujuan, nilai, dan prinsip demokrasi?; (4) Bagaimana hubungan antara negara dengan negara lain dan posisinya dalam menghadapi masalah-masalah internasional?; dan (5) Apa peran warga negara dalam demokrasi? Dengan demikian, materi pendidikan kewarganegaraan memuat hal-hal yang dapat menjawab kelima pertanyaan tersebut. Maiello (2003) mengemukakan bahwa civic knowledge dan civic skills dibutuhkan seseorang untuk 
memahami dengan baik berbagai informasi politik sehingga dapat memberikan penilaian politik dan berkontribusi untuk mengambil keputusan mengenai isu public dengan baik.

Civic skills atau keterampilan kewarganegaraan adalah keterampilan yang dikembangkan dari pengetahuan kewarganegaraan sehingga dapat digunakan dalam menghadapi masalah dalam kehidupan berbangsa dan bernegara. Keterampilan kewarganegaraan meliputi keterampilan intelektual (intellectual skill) dan keterampilan partisipasi (participation skill). Menurut NAEP, keterampilan intelektual yang dimaksud adalah keterampilan berpikir kritis yang mencakup keterampilan mengidentifikasi, mendeskripsikan, menjelaskan, menganalisis, mengevaluasi, menentukan, dan mempertahankan pendapat dalam hal yang berkaitan dengan masalah umum. Keterampilan partisipasi yang dimaksud meliputi keterampilan berinteraksi, memantau dan mempengaruhi orang lain (Komalasari, 2011). Whitacre (2004) mengemukakan bahwa civic skills memberikan pondasi untuk menjadi warga negara yang bertanggung jawab dan mengutamakan kepentingan umum di atas kepentingan pribadi. Keterampilan kewarganegaraan menjadi keterampilan dasar bagi peserta didik sebagai bekal dalam berkehidupan bermasyarakat dan bernegara (Nicotera, Brewer, \& DesMarais, 2013).

Civic disposition atau karakter kewarganegaraan memiliki tujuan utama yaitu membentuk warga negara yang berkarakter disiplin, tanggung jawab, peduli, sopan, sadar hukum, berpikir kritis, menghargai harkat dan martabat manusia, mampu mendengar, bernegosiasi dan kompromi (Mulyono, 2017). Dalam pembentukan karakter, pendidikan kewarganegaraan memiliki tiga domain, yaitu secara konseptual, kurikuler, dan sosio-kultural (Wahab \& Sapriya, 2010). Ketiga domain tersebut membuat pendidikan kewarganegaraan berperan dalam mengembangkan konsep dan teori, program pendidikan dan model implementasinya melalui lembaga pendidikan, serta melaksanakan proses pembelajaran bagi masyarakat sehingga diharapkan dapat menjadi warga negara yang baik.

\section{Penetapan Permasalahan}

\section{Hasil Kuesioner dan Wawancara}

Berdasarkan kuesioner dibagikan kepada 169 mahasiswa dari beberapa program studi di Universitas Tidar yang yang akan menempuh mata kuliah Kewarganegaraan pada semester 2 dan telah mengikuti perkuliahan Pendidikan Pancasila pada semester 1, didapat gambaran persepsi mahasiswa tentang mata kuliah Pendidikan Pancasila dan Kewarganegaraan.

\section{Tabel 1. Hasil Kuesioner Mahasiswa}

\begin{tabular}{|c|c|c|c|c|c|c|}
\hline No & Pertanyaan & $\begin{array}{l}\text { Sangat } \\
\text { Setuju } \\
(\%)\end{array}$ & $\begin{array}{l}\text { Setuju } \\
(\%)\end{array}$ & $\begin{array}{c}\text { Ragu } \\
(\%)\end{array}$ & $\begin{array}{l}\text { Tidak } \\
\text { Setuju } \\
\quad(\%)\end{array}$ & $\begin{array}{l}\text { Sangat } \\
\text { Tidak } \\
\text { Setuju } \\
(\%)\end{array}$ \\
\hline 1. & $\begin{array}{l}\text { Anda memilih mata kuliah Pendidikan } \\
\text { Pancasila dan mata kuliah Kewarganegaraan } \\
\text { karena Anda merasa mata kuliah itu penting. }\end{array}$ & 68,67 & 31,16 & 0 & 0,16 & 0 \\
\hline 2. & $\begin{array}{l}\text { Anda memilih mata kuliah Pendidikan } \\
\text { Pancasila dan mata kuliah Kewarganegaraan }\end{array}$ & 0,09 & 2,95 & 5,8 & 57,93 & 33,21 \\
\hline
\end{tabular}




\begin{tabular}{|c|c|c|c|c|c|c|}
\hline & $\begin{array}{l}\text { karena terpaksa dan tuntutan kewajiban di } \\
\text { Perguruan Tinggi. }\end{array}$ & & & & & \\
\hline 3. & $\begin{array}{l}\text { Mata kuliah Pendidikan Pancasila dan mata } \\
\text { kuliah Kewarganegaraan dihapuskan di } \\
\text { perguruan tinggi karena Pendidikan Pancasila } \\
\text { dan Kewarganegaraan sudah dipelajari di } \\
\text { tingkat SD, SMP, dan SMA/Sederajat. }\end{array}$ & 0,17 & 0,17 & 3,88 & 45,6 & 50,12 \\
\hline 4. & $\begin{array}{l}\text { Jika ada kesempatan memilih maka Anda lebih } \\
\text { memilih mata kuliah lain daripada mata kuliah } \\
\text { Pendidikan Pancasila dan mata kuliah } \\
\text { Kewarganegaraan. }\end{array}$ & 0,11 & 7,15 & 40,8 & 43,8 & 8,07 \\
\hline 5. & $\begin{array}{l}\text { Mata kuliah Pendidikan Pancasila mudah } \\
\text { dipahami dan mata kuliah Kewarganegaraan } \\
\text { juga akan mudah dipahami. }\end{array}$ & 6,4 & 51,8 & 38,5 & 2,85 & 0,4 \\
\hline 6. & $\begin{array}{l}\text { Mata kuliah Pendidikan Pancasila } \\
\text { membosankan dan mata kuliah } \\
\text { Kewarganegaraan juga akan membosankan. }\end{array}$ & 0,09 & 2,02 & 25,39 & 65,1 & 7,35 \\
\hline 7. & $\begin{array}{l}\text { Mata kuliah Pendidikan Pancasila } \\
\text { menyenangkan dan mata kuliah } \\
\text { Kewarganegaraan juga akan menyenangkan. }\end{array}$ & 10,6 & 57,02 & 31,77 & 0,4 & 0,1 \\
\hline
\end{tabular}

Sumber: Pengumpulan data diolah oleh Peneliti

Kuesioner ini menggambarkan bahwa mayoritas mahasiswa menyatakan bahwa mata kuliah Pendidikan Pancasila dan Kewarganegaran penting. Namun 5,8 persen mahasiswa masih ragu apakah dirinya merasa terpaksa untuk mengambil mata kuliah Pendidikan Pancasila dan mata kuliah Kewarganegaraan. Selain itu, terdapat kurang dari 5 persen mahasiswa yang menjadi responden menganggap bahwa mata kuliah Pendidikan Pancasila dan mata kuliah Kewarganegaraan kurang penting sehingga merasa terpaksa untuk mengambil perkuliahan tersebut.

Terkait kondisi pelaksanaan pembelajaran, terdapat lebih dari lima persen responden yang konsisten menganggap bahwa pembelajaran Pendidikan Pancasila yang telah ditempuh menyenangkan dan tidak membosankan, dan berharap bahwa gambaran ke depan untuk pembelajaran mata kuliah Kewarganegaraan juga akan menyenangkan. Meskipun demikian, terdapat lebih dari 25 persen dari responden yang masih ragu bahwa penyelenggaraan pembelajaran mata kuliah Pendidikan Pancasila menyenangkan atau tidak membosankan. Ini berarti diperlukan perbaikan metode pembelajaran mata kuliah Pendidikan Pancasila dan mata kuliah Kewarganegaraan.

Sesuai dengan hasil wawancara, sebagian besar mahasiswa menyukai kegiatan diskusi, tanya jawab, dan kegiatan di luar kelas sehingga tidak hanya mendengarkan ceramah. Mahasiswa tetap merasa membutuhkan penjelasan atau ceramah dari pendidik (guru/dosen) namun bukan setiap saat ceramah tanpa interaksi dengan peserta didik (siswa/mahasiswa) selama pembelajaran. Selain itu, sebagian mahasiswa merasa bahwa materi yang diberikan pada saat pelaksanaan pembelajaran di SD, SMP, dan SMA merupakan materi-materi yang sama dan terkesan diulang-ulang sehingga mengaharapkan pelaksanaan pembelajaran mata kuliah mata kuliah Kewarganegaraan tidak mengulang materi yang sudah dipahami. Terlebih lagi, sebagian mahasiswa tidak menyukai menghafal pasal-pasal dan tahun-tahun yang banyak dalam pembelajaran PKn/PPKn di sekolah. Oleh 
karena itu, mahasiswa berharap kegiatan perkuliahan khususnya mata kuliah Kewaragenagaraan dilaksanakan dengan aktif melibatkan mahasiswa dan menyenangkan. Mahasiswa menganggap bahwa dengan mengikuti pembelajaran mata kuliah Kewarganegaraan maka akan memberikan bekal dalam profesi apapun tetap membutuhkan pemahaman tentang bagaimana menjadi warna negara yang baik di dalam masyarakat.

\section{Pelaksanaan Pembelajaran dengan Model Belajar Berbasis Riset}

Sesuai dengan perencanaan, penelitian dilakukan dalam dua siklus tindakan. Siklus pertama diawali dengan penelitian pendahuluan untuk menetapkan permasalahan, sehingga ditemukan solusi yang diterapkan pada pembelajaran mata kuliah Kewarganegaraan yang melibatkan mahasiswa secara aktif dan menyenangkan. Mata kuliah Kewarganegaraan bukan hanya melakukan transfer pengetahuan kepada mahasiswa melainkan juga merubah perilaku mahasiswa sehingga menjadi warga negara yang baik. Oleh karena itu, pembelajaran mata kuliah Kewarganegaraan mencoba menggunakan model belajar berbasis riset dengan harapan mahasiswa dapat memiliki civic competence khususnya civic skills. Pelaksanaan model belajar berbasis riset diselenggarakan selama empat kali pertemuan yaitu pada materi Warga Negara dan Hak Asasi Manusia.

Kegiatan pembelajaran diawali dengan memberikan gambaran secara umum tentang warga negara, syarat-syarat menjadi warga negara Indonesia berdasarkan peraturan yang lama dan terbaru serta permasalahan yang dapat ditimbulkan terkait kewarganegaraan seseorang. Kemudian, mahasiswa dibagi menjadi beberapa kelompok dan masing-masing kelompok diberikan topik bahasan berbeda terkait materi utama. Mekanisme pembagian kelompok tidak dilaksanakan sebagaimana biasanya di mana langsung berhitung dari depan atau dari belakang, tetapi pembagian kelompok dilakukan dengan cara yang berbeda. Mahasiswa akan dibagi menjadi sepuluh kelompok. Masing-masing kelompok akan memiliki satu ketua dan tiga sampai empat anggota kelompok. Pemilihan anggota kelompok akan ditentukan oleh ketua kelompok masing-masing. Mahasiswa dapat mengajukan diri untuk menjadi ketua kelompok. Setelah ketua kelompok untuk sepuluh kelompok terpilih, masing-masing ketua kelompok kemudian memilih mahasiswa yang bersedia untuk menjadi anggota kelompoknya. Lalu dosen mengemukakan sepuluh topik bahasan untuk sepuluh kelompok. Masing-masing kelompok diberikan kebebasan untuk memilih topik yang akan dibahas dari sepuluh topik yang tersedia. Mekanisme pemilihan topik bahasan adalah dengan metode siapa cepat dia dapat. Sebelum pemilihan topik dilaksanakan, masing-masing kelompok diberikan waktu untuk berunding tentang topik yang mana yang akan dipilih. Kemudian dosen menyebutkan satu per satu topik bahasan secara acak dan kelompok yang berminat untuk membahasnya maka cukup mengangkat tangan. Setelah semua kelompok telah memiliki topik bahasan masing-masing, kelompok diberikan waktu untuk mengerjakannya dan mempresentasikannya pada pertemuan berikutnya. Mekanisme pemilihan ketua dan anggota kelompok serta pemilihan topik pembahasan tersebut melatih mahasiswa untuk memiliki keterampilan kewarganegaraan yaitu keterampilan partisipasi. Menurut NAEP, Keterampilan partisipasi yang dimaksud 
meliputi keterampilan berinteraksi, memantau dan mempengaruhi orang lain (Komalasari, 2011). Apabila terdapat dua atau lebih kelompok yang kebetulan memilih topik bahasan yang sama maka dosen memberikan kesempatan bagi kelompok yang bersangkutan untuk bermediasi hingga memperoleh keputusan yang disetujui masing-masing kelompok yang bersangkutan.

Pada saat pengumpulan data terkait topik bahasan yang dipilih, masingmasing kelompok dapat mengumpulkan data melalui studi dokumentasi dan diwajibkan untuk melakukan wawancara kepada minimal dua responden yang dianggapnya sesuai dengan topik bahasan. Setelah data diperoleh, masing-masing kelompok menulis laporan dengan format penulisan yang telah ditentukan. Format penulisan laporan yang ditentukan antara lain: ukuran margin kiri $4 \mathrm{~cm}$, atas $3 \mathrm{~cm}$, kanan $3 \mathrm{~cm}$, bawah $3 \mathrm{~cm}$; ukuran font 12; huruf times new roman; ukuran kertas A4; spasi 1,5; dengan cover yang memuat judul topik bahasan, logo universitas, nama anggota kelompok, nama program studi, fakultas, universitas, dan tahun pengerjaan; halaman selanjutnya daftar isi; batang tubuh laporan terdiri atas uraian topik bahasan berdasarkan hasil wawancara dan studi dokumentasi, analisis kelompok terhadap topik pembahasan serta daftar pustaka. Lalu pada saat presentasi dalam diskusi kelompok besar di kelas, masing-masing kelompok membuat power point. Proses pengerjaan tugas tersebut melatih mahasiswa untuk memiliki keterampilan kewarganegaraan yang lainnya yaitu keterampilan intelektual. Menurut NAEP, keterampilan intelektual yang dimaksud adalah keterampilan berpikir kritis yang mencakup keterampilan mengidentifikasi, mendeskripsikan, menjelaskan, menganalisis, mengevaluasi, menentukan, dan mempertahankan pendapat dalam hal yang berkaitan dengan masalah umum (Komalasari, 2011).

Pada siklus pertama, yang dilaksanakan tiga kali pertemuan, terdapat pada pertemuan pertama dua mahasiswa yang memiliki keberanian untuk bertanya tentang materi pembelajaran kepada dosen. Pada pertemuan kedua, ada enam mahasiswa yang tidak hanya bertanya pada dosen, tetapi juga menanggapi kelompok yang presentasi. Pada pertemuan ketiga, ada 11 mahasiswa yang bertanya, menanggapi, dan membantu kelompok lain dalam menjawab pertanyaan dari forum.

Hasil refleksi siklus satu menunjukkan bahwa mahasiswa-mahasiswa yang ketika mendapatkan tugas riset terkait suatu topik pembahasan secara bersama terjun ke lapangan untuk wawancara maupun mengumpulkan data melalui studi dokumentasi. Kemudian mahasiswa secara aktif berdiskusi hingga penulisan laporan kerja kelompoknya membutuhkan waktu lebih dari satu kali pertemuan perkuliahan. Selain itu, mahasiswa belajar untuk menjelaskan hasil dan menanggapi pertanyaan-pertanyaan yang diberikan baik oleh sesama mahasiswa maupun oleh dosen. Selama berdiskusi baik dalam kelompok kecil maupun kelompok besar, mahasiswa dilatih untuk berpikir kritis. Apabila pembelajaran dilaksanakan dengan ceramah dan tanya jawab pada setiap kali pertemuan maka baik yang bertanya maupun yang memberikan pendapat cenderung dilakukan oleh mahasiswamahasiswa tertentu. Stimulus yang mengandung motivasi dapat meningkatkan perhatian dan semangat belajar mahasiswa (Bourgeois, Chelazzi, \& Vuilleumier, 2016). Hal ini dilakukan sebagai upaya untuk mendorong rasa percaya diri mahasiswa dalam mengajukan pertanyaan atau tanggapan. 
Berdasarkan hasil refleksi siklus satu dilakukan perbaikan proses pembelajaran baik dari segi persiapan dan penyempurnaan strategi dan media. Maka pada siklus kedua, terjadi peningkatan keaktifan mahasiswa. Pada pada minggu pertama di siklus kedua, sudah tampak mahasiswa tidak lagi hanya bertanya tetapi sudah menanggapi pendapat teman-temannya. Pada minggu berikutnya ada interaksi pembelajaran yang terus meningkat tidak hanya antara dosen dengan mahasiswa tetapi juga antara mahasiswa dengan mahasiswa dan mahasiswa kepada dosen meminta kejelasan konsep. Ketika mahasiswa dilibatkan dalam proses belajar secara aktif maka akan terjadi peningkatan dalam pembelajarannya (Lumpkin, Achen, \& Dodd, 2015).

Hasil refleksi dari pelaksanaan siklus di atas adalah kebutuhan mahasiswa beraneka ragam. Dosen perlu menggunakan model pembelajaran atau metode pembelajaran yang tidak monoton khususnya pada pembelajaran mata kuliah Kewarganegaraan dengan materi yang luas namun jumlah jam pembelajaran di kelas yang terbatas. Ketika mahasiswa diberikan tanggung jawab tertentu misalnya melakukan riset sederhana dan mempresentasikan hasilnya di depan kelas maka mahasiswa yang bersangkutan belajar untuk aktif. Kekurangannya adalah ketika beberapa mahasiswa yang kurang memiliki kepercayaan diri maka mahasiswamahasiswa tersebut apabila memiliki pertanyaan atau tanggapan maka cenderung dititipkan kepada mahasiswa yang terbiasa berpendapat. Namun, apabila perkuliahan hanya dilakukan dengan metode ceramah dan tanya jawab maka aspek yang cenderung dominan adalah aspek pengetahuan. Sedangkan mata kuliah Kewarganegaraan diharapkan peserta didik dapat mengalami perubahan perilaku yaitu dapat menjadi warga negara yang baik dengan memiliki pengetahuan kewarganegaraan, keterampilan kewarganegaraan, dan watak kewarganegaraan. Oleh karena itu, model belajar berbasis riset penting digunakan karena menggabungkan metode ceramah, tanya jawab, diskusi, hingga penggunan pendekatan riset dalam pembelajaran. Dengan demikian, aspek pengetahuan, sikap, dan keterampilan yang berusaha untuk diajarkan dari pembelajaran mata kuliah Kewarganegaraan dapat diupayakan untuk terpenuhi.

\section{SIMPULAN}

Berdasarkan uraian hasil temuan serta pembahasan maka dapat disimpulkan bahwa ketika mahasiswa diberikan tanggung jawab tertentu misalnya melakukan riset sederhana dan mempresentasikan hasilnya di depan kelas maka mahasiswa yang bersangkutan belajar untuk aktif. Terlebih lagi terdapat mahasiswa-mahasiswa yang ketika mendapatkan tugas riset terkait suatu topic pembahasan secara bersama terjun ke lapangan baik wawancara maupun pengumpulan data melalui studi dokumentasi. Kemudian mahasiswa secara aktif berdiskusi hingga penulisan laporan kerja kelompoknya membutuhkan waktu lebih dari satu kali pertemuan perkuliahan. Selain itu, mahasiswa belajar untuk menjelaskan hasil dan menanggapi pertanyaan-pertanyaan yang diberikan baik oleh sesama mahasiswa maupun oleh dosen. Selama berdiskusi baik dalam kelompok kecil maupun kelompok besar, mahasiswa dilatih untuk berpikir kritis. Apabila pembelajaran dilaksanakan dengan ceramah dan tanya jawab pada setiap kali pertemuan maka baik yang bertanya 
maupun yang memberikan pendapat cenderung dilakukan oleh mahasiswamahasiswa tertentu. Ketika beberapa mahasiswa yang kurang memiliki kepercayaan diri maka mahasiswa-mahasiswa tersebut apabila memiliki pertanyaan atau tanggapan maka cenderung dititipkan kepada mahasiswa yang terbiasa berpendapat. Dengan demikian, penerapan model belajar berbasis riset dapat mengembangkan keterampilan kewarganegaraan mahasiswa pada mata kuliah Kewargenageraan.

\section{REFERENSI}

Bourgeois, A., Chelazzi, L., \& Vuilleumier, P. (2016). How motivation and reward learning modulate selective attention. In Progress in brain research (Vol. 229, pp. 325-342). Elsevier.

Branson, M. S. (1999). Belajar civic education dari Amerika. Yogyakarta: Kerja LKIS dan The Asia Foundation.

Creswell, J. (2016). Research Design: Pendekatan Metode Kualitatif, Kuantitatif. Yogyakarta: Pustaka Pelajar.

Hafsah, U. (2017). Implementasi Riset Based Learning dalam Upaya Peningkatan Kualitas Pembelajaran. Kumpulan Jurnal Dosen Universitas Muhammadiyah Sumatera Utara, (8).

Harsono, H. (2008). Student-centered learning di perguruan tinggi. Jurnal Pendidikan Kedokteran Dan Profesi Kesehatan Indonesia, 3(1), 4-8.

Komalasari, K. (2011). Kontribusi Pembelajaran Kontekstual untuk Pengembangan Kompetensi Kewarganegaraan Peserta Didik SMP di Jabar. Mimbar: Jurnal Sosial Dan Pembangunan, 27(1), 47-55.

Kusnadi, E. (2010). Pembelajaran Kooperatif (Cooperative Learning) Tipe Jigsaw dalam Pendidikan Kewarganegaraan untuk Meningkatkan Pengetahuan Kewarganegaraan Siswa: Penelitian Tindakan Kelas pada Siswa Kelas X Administrasi Perkatoran di SMK Wirakarya Ciparay Kabupaten Bandung. Universitas Pendidikan Indonesia.

Legiman. (2015). Penelitian tindakan kelas (PTK). Yogyakarta.

Lumpkin, A., Achen, R. M., \& Dodd, R. K. (2015). Using Technology-Nested Instructional Strategies to Enhance Student Learning. Insight: A Journal of Scholarly Teaching, 10, 114-125.

Maiello, C., Oser, F., \& Biedermann, H. (2003). Civic knowledge, civic skills and civic engagement. European Educational Research Journal, 2(3), 384-395.

Miles, M. B., Huberman, A. M., \& Saldana, J. (2014). Qualitative data analysis: A methods sourcebook. New York: Sage.

Mulyono, B. (2017). Reorientasi civic disposition dalam kurikulum Pendidikan Kewarganegaraan sebagai upaya membentuk warga negara yang ideal. Jurnal Civics: Media Kajian Kewarganegaraan, 14(2), 218-225.

Nicotera, N., Brewer, S., \& DesMarais, E. (2013). Developing the civic skills of public school youth: A mixed methods assessment. The International Journal of Research on Service-Learning and Community Engagement, 1(1).

Pratama, A. B. (2017). Jurnal Ilmiah sebagai Bahan Pembelajaran Berbasis Riset pada Pendidikan Sarjana Administrasi Negara. Journal of Public Administration and Local Governance, 1(1), 10-19.

Rangkuti, A. N. (2017). Pembelajaran Berbasis Riset di Perguruan Tinggi. 
PROCEEDING IAIN Batusangkar, 1(1), 141-152.

Setiawan, D. (2015). Pendidikan Kewarganegaraan Berbasis Karakter melalui Penerapan Pendekatan Pembelajaran Aktif, Kreatif, Efektif dan Menyenangkan. JUPIIS: Jurnal Pendidikan Ilmu-Ilmu Sosial, 6(2), 61-72.

Sukarno. (2018). Model Belajar Berbasis Riset di Universitas Tidar. Magelang: Fakultas Keguruan dan Ilmu Pendidikan Universitas Tidar.

Wahab, A. A., \& Sapriya. (2010). Teori dan landasan pendidikan kewarganegaraan. Bandung: Alfabeta.

Whitacre, E. (2004). Civic Skills. Retrieved from https://www.learningtogive.org/resources/civic-skills\%0A\%0A 